\title{
Hubungan antara Minat Belajar dengan Hasil Belajar Matematika pada Siswa Kelas V SD Negeri 04 Sila
}

\author{
Suciyati ${ }^{1}$, Mariamah $^{2}$ \\ ${ }^{1,2}$ STKIP Taman Siswa Bima \\ 1'suciyati.yasin@gmail.com
}

\begin{abstract}
ABSTRAK
Tujuan dari penelitian ini adalah untuk mengetahui (1) minat belajar matematika siswa kelas V SD Negeri 04 Sila. (2) hasil belajar matematika siswa kelas V SD Negeri 04 Sila. (3) hubungan antara minat belajar dengan hasil belajar matematika siswa kelas V SD Negeri 04 Sila. Penelitian ini merupakan jenis penelitian kuantitatif-korelatif. Populasi dalam penelitian ini adalah seluruh siswa kelas V SD Negeri 04 Sila yang berjumlah 20 orang. Teknik pengambilan sampel dari penelitian ini menggunakan teknik sampling jenuh artinya semua anggota populasi sebagai sampel yakni berjumlah 20 orang. Instrumen penelitian ini berupa angket minat belajar matematika dan dokumentasi. Teknik pengolahan data dan analisis data adalah statistik deskriptif dan statistik inferensial. Hasil penelitian yang didapat adalah sebagai berikut untuk minat belajar dan hasil belajar matematika siswa kelas V SD berdasarkan perhitungan bahwa minat belajar dan hasil belajar matematika berada pada kategori sedang dengan persentase 55\% untuk minat dan 45\% untuk hasil belajar. hasil pengujian hipotesis, minat belajar terhadap hasil belajar matematika menunjukan hubungan dengan nilai $r_{\text {hitung }} 0,584>r_{\text {tabel }} 0,444$ dengan taraf signifikan $5 \%$ dan $t_{\text {hitung }} 3,019>t_{\text {tabel }} 1,734$ dengan taraf signifika $\alpha=0,05$ maka $\mathrm{H}_{\mathrm{i}}$ diterima dan $\mathrm{H}_{\mathrm{o}}$ ditolak. Berdasarkan hasil penelitian ini dapat disimpulkan bahwa terdapat hubungan antara minat belajar dengan hasil belajar matematika pada siswa kelas V SD Negeri 04 Sila.
\end{abstract}

Kata Kunci: Minat belajar, Hasil belajar, Matematika

\section{PENDAHULUAN}

Pendidikan merupakan salah satu hal yang pokok dalam kehidupan manusia. Pendidikan di Indonesia terbagi dalam tiga jalur, yaitu pendidika formal, pendidikan informal, dan pendidikan non-formal (UU No. 20 tahun 2003 pasal 13 ayat 1). Salah satu bentuk pendidikan formal adalah pendidikan yang diselenggarakan di sekolah. Sekolah merupakan tempat bertemunya siswa dan guru dalam melaksanakan kegiatan pembelajaran. Dalam kegiatan pembelajaran proses yang harus dilakukan adalah merencanakan, melaksanakan, dan mengevaluasi. Evaluasi adalah kegiatan mengukur dan menilai hasil belajar siswa yang kemudian digunakan untuk mengetahui keberhasilan siswa dalam belajar.

Salah satu aspek pendukung keberhasilan siswa dalam belajar adalah minat belajar. Minat belajar merupakan rasa tertarik atau kecenderungan melakukan suatu kegiatan untuk memperoleh pengetahuan atau perubahan prilaku sebagai hasil pengalamannya sendiri dalam interaksi dengan lingkungannya. Hal itu diperkuat dengan pendapat yang di kemukakan oleh Djamarah (2011:148) bahwa dalam proses belajar, minat sangat diperlukan, sebab siswa yang tidak mempunyai minat dalam belajar tak akan mungkin melakukan aktivitas belajar. Minat bukan saja mempengaruhi tingkah laku siswa tapi juga dapat mendorong siswa untuk tetap melakukan sesuatu. Dalam kegiatan belajar, minat mempunyai peranan yang sangat penting. Bila siswa tidak memiliki minat dan perhatian yang besar terhadap objek yang dipelajari maka sulit diharapkan siswa tersebut akan tekun dan memperoleh hasil yang baik dari belajarnya. Sebaliknya, apabila siswa tersebut belajar dengan minat danperhatian besar terhadap objek yang dipelajari, maka hasil yang diperoleh lebih baik.

Selain minat belajar ada aspek lain yang turut berpengaruh terhadap keberhasilan siswa dalam belajar, aspek tersebut adalah hasil belajar. Hasil belajar merupakan sesuatu yang diperoleh setelah 
proses pembelajaran selesai. Hal itu sependapat dengan yang dikemukakan oleh Sudjana (2014:22) bahwa hasil belajar adalah kemampuan- kemampuan yang dimiliki siswa setelah siswa menerima pengalaman belajarnya. Menurut hordword kingsleydalam bukunya Sudjana membagi tiga macam hasil belajar mengajar: 1) Keterampilan dan kebiasaan, 2) Pengetahuan dan pengertian, 3) Sikap dan citacita, (Sudjana, 2014:22). Hasil belajar mempunyai peranan penting dalam proses pembelajaran karena akan memberikan sebuah informasi kepada guru tentang kemajuan siswa dalam upaya mencapai tujuan-tujuan belajarnya.

Pelajaran Matematika merupakan salah satu pelajaran yang mendapat prioritas untuk dikembangkan, karena matematika merupakan sarana untuk memecahkan masalah dalam kehidupan sehari-hari (Adiansha, dkk, 2017). Banyak peserta didik beranggapan bahwa pelajaran matematika merupakan pelajaran yang sulit dan cukup berat dikuasai, hal ini disebabkan karena kurangnya minat siswa terhadap pelajaran matematika sehingga berpengaruh pada hasil belajar atau ketuntasan belajar siswa. Menurut Depdikbub, 1995 Seorang siswa dikatakan tuntas belajar apabila telah mencapai taraf serap minimal 65\% dan klasikal apabila 85\% siswa pada materi itu tuntas belajar.

Dikarenakan dalam penelitian ini peneliti ingin mengetahui adakah hubungan antara minat belajar dengan hasil belajar matematika siswa kelas V SD, maka dalam hal ini peneliti melakukan observasi di SD Negeri 04 Sila. Berdasarkan wawancara dengan guru kelas $\mathrm{V}$ di SD Negeri 04 Sila didapatkan bahwa hasil belajar matematika siswa kelas $\mathrm{V}$ masih rendah dan belum mencapai Kriteria ketuntasan minimal (KKM)yang telah ditetapkan dalam petunjuk pelaksanaan evaluasi kurikulum, yaitu $85 \%$ dari jumlah siswa yang memperoleh nilai $\geq 70$. Guru menjelaskan beberapa penyebab hasil belajar siswa rendah adalah karena kurangnya minat belajar siswa pada mata pelajaran matematika.

Pada saat aktivitas pembelajaran matematika berlangsung perhatian siswa rendah. Hal ini ditunjukkan pada saat guru memberikan penjelasan, siswa kurang memperhatikan. Hanya ada beberapa siswa yang memperhatikan penjelasan guru. Sementara siswa yang lain memperhatikan obyek lain seperti mengobrol dengan teman semeja, bermain alat tulis, serta tiduran dengan meletakkan kepala di atas meja. Keaktifan siswa saat pembelajaran rendah. Hal ini ditunjukkan pada saat guru mengajukan pertanyaan, hanya beberapa siswa yang menjawab pertanyaan guru. Begitu juga saat guru memberikan kesempatan siswa untukbertanya tidak ada siswa yang mengajukan pertanyaan berkaitan dengan materi pelajaran matematika yang disampaikan guru. Faktor intern yang mempengaruhi belajar dan hasil belajar salah satunya adalah minat. Beberapa gejala yang telah dipaparkan di atas, yaitu masih rendahnya perhatian dan aktifitas siswa menunjukkan bahwa minat belajar matematika pada siswa kelas $\mathrm{V}$ masih rendah. Yang kemudian berpengaruh pada hasil belajar siswa pada mata pelajaran matematika.

Dalyono (2009: 56) menyebutkan minat belajar yang besar cenderung menghasilkan hasil belajar yang tinggi, sebaliknya jika minat belajar kurang maka akan menghasilkan hasil belajar yang rendah. Minat dapat timbul karena adanya daya tarik dari luar dan juga datang dari hati sanubari. Minat yang besar memudahkan untuk mencapai tujuan yang diminati. Minat belajar dapat timbul disebabkan beberapa hal, antara lain adanya keinginan yang kuat untuk menaikkan atau memperoleh pekerjaan yang baik serta ingin hidup senang dan bahagia. Senada dengan pendapat di atas, Slameto (2013: 57) menyatakan minat belajar memiliki pengaruh yang besar terhadap hasil belajar, karena jika bahan pelajaran yang dipelajari tidak sesuai dengan minat siswa, siswa tidak akan belajar dengan baik. Jika belajar tanpa disertai minat, siswa akan malas dan tidak akan mendapatkan kepuasan dalam mengikuti pembelajaran.

Untuk dapat melihat keberhasilan proses kegiatan pembelajaran, seluruh faktor-fakor yang berhubungan dengan guru dan siswa harus dapat diperhatikan. Mulai dari perilaku guru dalam mengajar sampai dengan tingkah laku siswa sebagai timbal balik dari hasil sebuah pengajaran. Tingkah laku siswa ketika mengikuti proses 
pembelajaran dapat mengindikasikan akan ketertarikan siswa tersebut terhadap pelajaran itu atau sebaliknya. Ketertarikan siswa inilah yang merupakan salah satu tanda-tanda minat. Menurut Syah (2011:152) Minat adalah kecenderungan dan kegairahan yang tinggi atau keinginan yang besar terhadap sesuatu. Sementara itu Slameto (2010:180) mengatakan bahwa Minat adalah suatu rasa lebih suka dan rasa ketertarikan pada suatu hal atau aktivitas, tanpa ada yang menyuruh.

Berdasarkan pengertian tersebut dapat disimpulkan bahwa minat akan timbul apabila mendapatkan rangsangan dari luar. Sehingga kecenderungan untuk merasa tertarik pada suatu bidang bersifat menetap dan merasakan perasaan yang senang apabila ia terlibat aktif didalamnya. Meskipun perasaan senang ini timbul dari lingkungan atau berasal dari objek yang menarik. Menurut Slameto (2010: 2) Belajar ialah suatu proses usaha yang dilakukan seseorang untuk memperoleh suatu perubahan tingkah laku yang baru secara keseluruhan, sebagai hasil pengalamannya sendiri dalam interaksi dengan lingkungannya. Sedangkan menurut suyono dan hariyanto (2012: 9) Belajar adalah suatu aktivitas atau suatu proses untuk memperoleh pengetahuan, peningkatan keterampilan, memperbaiki prilaku, sikap, dan mengokohkan kepribadian. Selain itu Gagne dalam Suprijono (2013: 2) menyatakan bahwa belajar adalah perubahan disposisi atau kemampuan yang dicapai seseorang melalui aktivitas.

Berdasarkan pembahasan diatas maka dapat disimpulkan bahwa minat belajar adalah rasa tertarik atau kecenderungan melakukan suatu kegiatan untuk memperoleh pengetahuan atau perubahan prilaku sebagai hasil pengalamannya sendiri dalam interaksi dengan lingkungannya. Dengan demikian, apabila seorang guru ingin berhasil dalam melakukan kegiatan pembelajaran harus dapat memberikan rangsangan kepada siswa agar berminat dalam mengikuti proses kegiatan pembelajaran tersebut. Apabila siswa sudah merasa berminat mengikuti pelajaran, maka ia akan menangkap dan mengerti dengan mudah apa yang di sampaikan oleh guru, begitu juga sebaliknya apabila siswa merasakan tidak berminat dalam melakukan proses kegiatan pembelajaran ia akan merasa tersiksa, jenuh, dan bosan dalam mengikuti pelajaran tersebut.

Seperti yang telah dikemukakan bahwa minat dapat diartikan sebagai suatu ketertarikan terhadap suatu objek yang kemudian mendorong individu untuk mempelajari dan menekuni segala hal yang berkaitan dengan minatnya tersebut. Maka minat yang diperoleh melalui adanya suatu proses belajar dikembangkan melalui proses menilai suatu objek yang kemudian menghasilkan suatu penilaian-penilaian tertentu terhadap objek yang menimbulkan minat seseorang. Penilaian-penilaian terhadap objek yang diperoleh melalui proses belajar itulah yang kemudian menghasilkan suatu keputusan mengenal adanya ketertarikan atau ketidaktertarikan seseorang terhadap objek yang dihadapinya.

Menurut Lilawati dalam zusnani (2013:79) mengartikan minat adalah suatu perhatian yang kuat dan mendalam disertai dengan perasaan senang terhadap suatu kegiatan sehingga mengarahkan anak untuk melakukan kegiatan tersebut dengan kemauan sendiri. Hurlock (1990: 422) mengatakan bahwa minat merupakan hasil dari pengalaman atau proses belajar. Ia mengemukakan bahwa minat memiliki dua aspek yaitu: Aspek kognitif, Aspek ini didasarkan atas konsep yang dikembangkan seseorang mengenai bidang yang berkaitan dengan minat. Konsep yang membangun aspek kognitif didasarkan atas pengalaman dan apa yang dipelajari dari lingkungan. Aspek ke dua adalah Aspek afektif, Aspek afektif ini adalah konsep yang membangun konsep kognitif dan dinyatakan dalam sikap terhadap kegiatan atau objek yang menimbulkan minat. Aspek ini mempunyai peranan yang besar dalam memotivasikan tindakan seseorang. Berdasarkan uraian tersebut, maka minat terhadap mata pelajaran matematika yang dimiliki seseorang bukan bawaan sejak lahir, tetapi dipelajari melalui proses penilaian kognitif dan penilaian afektif seseorang yang dinyatakan dalam sikap. Dengan kata lain, jika proses penilaian kognitif dan afektif seseorang terhadap objek minat adalah positif maka akan 
menghasilkan sikap yang positif dan dapat menimbulkan minat.

Slameto (2010:180) menyatakan bahwa Minat adalah suatu rasa lebih suka dan rasa ketertarikan pada suatu hal atau aktivitas, tanpa ada yang menyuruh. Minat pada dasarnya adalah penerimaan akan suatu hubungan antara diri sendiri dengan sesuatu di luar diri. Semakin kuat atau dekat hubungan tersebut semakin besar minat. Suatu minat dapat diekspresikan melalui suatu pernyataan yang menunjukkan bahwa siswa lebih menyukai suatu hal dari pada hal lainnya, dapat pula dimanifestasikan melalui partisipasi dalam suatu aktivitas. Siswa yangmemiliki minat terhadap subjek tertentu cenderung untuk memberikan perhatian yang lebih besar terhadap subjek tertentu.

Berdasarkan definisi tersebut, maka dapat disimpulkan indikator minat belajar yaitu rasa suka/senang dalam aktivitas belajar, rasa ketertarikan untuk belajar, adanya kesadaran untuk belajar tanpa disuruh, berpartisipasi dalam aktivitas belajar, memberikan perhatian yang besar dalam belajar. Ada beberapa indikator yang mempengaruhi minat belajar siswa antara lain: 1) Rasa tertarik2) Perasaan senang 3) Perhatian 4) Partisipasi 5) Keinginan/kesadaran (Safari dalam Herlina, 2010:20) Indikator-indikator tersebut di atas dapat dijelaskan sebagai berikut: 1) Rasa tertarik, tertarik adalah merupakan awal dari individu menaruh minat, sehingga seseorang yang menaruh minat akan tertarik terlebih dahulu terhadap sesuatu. Ketertarikan yang dimaksud adalah ketertarikan terhadap pelajaran di kelas; 2) Perasaan senang, perasaan merupakan unsur yang tak kalah penting bagi anak didik terhadap pelajaran yang diajarkan oleh gurunya. Seorang siswa yang memiliki perasaan senang atau suka terhadap suatu mata pelajaran, maka siswa tersebut akan terus mempelajari ilmu yang disenanginya. Tidak ada perasaan terpaksa pada siswa untuk mempelajari bidang tersebut; 3) Perhatian, menurut Gazali dalam Slameto (2010: 56) perhatian adalah keaktifan jiwa yang dipertinggi, jiwa itu pun semata-mata tertuju kepada suatu obyek (benda/ hal) atau sekumpulan objek. Untuk dapat menjamin hasil belajar yang baik, maka siswa harus mempunyai perhatian terhadap bahan yang dipelajarinya, jika bahan pelajaran tidak menjadi perhatian siswa, maka timbullah kebosanan, sehingga ia tidak lagi suka belajar. Aktivitas yang disertai dengan perhatian intensif akan lebih sukses dan prestasinya pun akan lebih tinggi. Maka dari itu sebagai seorang guru harus selalu berusaha untuk menarik perhatian anak didiknya sehingga mereka mempunyai minat terhadap pelajaran yang diajarkan. Siswa yang menaruh minat pada suatu mata pelajaran akan memberikan perhatian yang besar. Ia akan menghabiskan banyak waktu dan tenaga untuk belajar mata pelajaran yang diminatinya. Siswa tersebut pasti akan berusaha keras untuk memperoleh nilai yang bagus yaitu dengan belajar; 4) Partisipasi, partisipasi merupakan keikutsertaan siswa dalam proses pembelajaran. Siswa yang mempunyai minat terhadap suatu pelajaran akan melibatkan dirinya dan berpartisipasi aktif dalam hal-hal yang berkaitan dengan kegiatan pembelajaran yang diminatinya. Partisipasi siswa dalam proses pembelajaran bisa dilihat dari sikap siswa yang partisipatif. Siswa rajin bertanya dan mengemukakan pendapatnya. Selain itu siswa selalu berusaha terlibat atau mengambil andil dalam setiap kegiatan; 5) Keinginan/kesadaran, siswa yang mempunyai minat terhadap suatu pelajaran akan berusaha belajar dengan baik. Siswa mempunyai rasa ingin tahu yang tinggi dan mempunyai kesadaran untuk belajar tanpa ada yang menyuruh dan memaksa. Faktor-faktor yang Mempengaruhi Minat Belajar Salah satu pendorong dalam keberhasilan belajar adalah minat.

Purwanto (2008:44) mengungkapkan hasil belajar dapat dijelaskan dengan memahami dua kata yang membentuknya, yaitu hasil dan belajar. Pengertian hasil menunjuk pada suatu perolehan akibat dilakukannya suatu aktivitas atau proses yang mengakibatkan berubahnya input secara fungsional. Jadi hasil belajar merupakan perubahan yang mengakibatkan manusia berubah dalam tingkah laku dan secara khusus pengetahuannnya.

Nana Sudjana (2009: 2) menjelaskan bahwa hasil belajar adalah suatu proses yang ditandai dengan adanya perubahan pada diri seseorang. 
Perubahan sebagai hasil dariproses belajar ditunjukkan dalam berbagai bentuk seperti perubahan sikap, tingkah laku serta perubahan aspek lain yang ada pada individu yang belajar. Lebih lanjut Rohwati (2010: 76) mengungkapkan hasil belajar merupakan hal yang penting yang akan dijadikan tolok ukur keberhasilan peserta didik dalam belajar dansejauh mana sistem pembelajaran yang diberikan guru berhasil atau tidak. Suatu proses belajar mengajar dikatakan berhasil apabila kompetensi dasar yang diinginkan tercapai.

Berdasarkan penjelasan di atas dapat disimpulkan bahwa hasil belajar adalah kemampuan yang dimiliki peserta didik setelah melakukan aktivitas belajar yang ditandai oleh tercapainya suatu tujuan belajar berupa perubahan tingkah laku, bertambahnya pengetahuan dan memiliki suatu keterampilan.

\section{METODE}

Jenis penelitian yang digunakan dalam penelitian ini adalah penelitian korelasional. Pendekatan yang digunakan dalam penelitian ini adalah pendekatan kuantitatif. Pendekatan kuantitatif yaitu penelitian yang banyak menggunakan angka, mulai dari pengumpulan data, penafsiran data, serta penampilan dari hasilnya (Suharsimi Arikunto, 2006 :12). Digunakannya pendekatan kuantitatif karena dengan memperhatikan tujuan yang ingin dicapai dan manfaatnya serta masalah yang ingin diselesaikan, yakni mencari "Hubungan antara Minat Belajar dengan Hasil Belajar Matematika siswa kelas V SD Negeri 04 Sila”.

Dalam penelitian ini, variabel yang digunakan adalah variabel bebas (independen) dan variabel terikat (dependen). Adapun rancangan penelitiannya adalah:

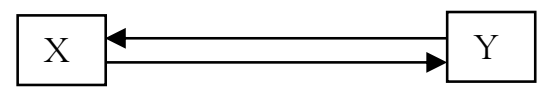

Gambar 1. Rancangan Penelitian (Sugiono, 2006)

Keterangan:

$\mathrm{X}=$ Minat Belajar Matematika

$\mathrm{Y}=$ Hasil Belajar Matematika

Penelitian ini dirancang untuk menentukan besarnya hubungan variabel X (minat belajar matematika) dengan variabel $\mathrm{Y}$ (hasil belajar matematika). Besarnya hubungan antara variabel $\mathrm{X}$ dan variabel $\mathrm{Y}$ diperoleh dengan membagikan angket minat belajar matematika kepada siswa untuk dikerjakan. Angket tersebut selanjutnya dinilai dan dianalisis untuk melihat hubungannya dengan hasil belajar.

Populasi dalam penelitian ini adalah seluruh siswa kelas V SD. Adapun yang menjadi sampel dalam penelitian ini adalah siswa kelas V SD Negeri 04 Sila yang berjumlah 20 orang siswa yang terdiri dari 10 orang siswa perempuan dan 10 orang siswa laki-laki. Instrumen penelitian sangat penting dalam pengumpulan data. Instrumen pengumpulan data yang digunakan dalam penelitian ini adalah dengan menggunakan angket atau kuisioner dan format dokumentasi.

Teknik statistik deskriptif adalah statistik yang digunakan untuk menganalisa data dengan cara menggambarkan data yang telah dikumpulkan sebagaimana adanya tanpa bermaksud membuat kesimpulan yang berlaku secara umum atau gneralisasi. Analisis data diskriptif digunakan untuk menjawab permasalahan bagaimana minat belajar matematika siswa dan hasil belajar matematika siswa kelas V SD Negeri 04 Sila (rumusan masalah pertama dan kedua).

Data yang di deskripsikan yaitu data minat belajar dan hasil belajar matematika siswa kelas V SD Negeri 04 Sila yang berjumlah 20 orang. Dalam penelitian ini peneliti ingin mengetahui seberapa besar hubungan antara minat belajar dengan hasil belajar matematika, oleh sebab itu peneliti nanti akan mengelompokan siswa dalam 3 tingkatan sesuai dengan minat belajar dan hasil belajar siswa yakni siswa yang memiliki minat dan hasil belajar yang tinggi, sedang dan rendah.

Untuk menentukan teknik uji hipotesis pada penelitian sampel dilakukan uji prasyarat terlebih dahulu, yaitu uji normalitas dan linieritas. Jika kedua prasyarat terpenuhi maka dapat dilanjutkan dengan statistik parametrik, namun jika tidak terpenuhi maka dapat menggunakan statistik non-parametrik. 


\section{HASIL DAN PEMBAHASAN}

Penelitian ini dilaksanakan pada kelas V SD Negeri 04 Sila. Data yang dikumpulkan merupakan data kuantitatif yang diperoleh dari angket minat belajar siswa pada mata pelajaran Matematika (variabel X) dan hasil belajar siswa berupa nilai ulangan tengah semester (UTS) pada pelajaran Matematika (variabel Y). Adapun deskripsi data hasil penelitiannya adalah sebagai berikut:

\section{Deskripsi Minat Belajar}

Data Minat Belajar

Data minat belajar diperoleh dari angket minat belajar dengan empat pilihan jawaban yaitu sangat setuju, setuju, tidak setuju, dan sangat tidak setuju. Penskoran yang digunakan dalam angket minat belajar memiliki rentan $1-4$. skor untuk jawaban sangat setuju 4, setuju 3, tidak setuju 2, dan sangat tidak setuju 1. Angket minat belajar terdiri atas 20 pertanyaan yang telah di uji kevalidannya.

Dalam penelitian ini hasil angket minat belajar yang diperoleh siswa mempunyai skor terendah 40 dan skor tertinggi 65 .

\section{Kategori Minat Belajar}

Tingkat minat belajar matematika siswa kelas $\mathrm{V}$ dapat diketahui dengan cara penentuan kategorisasi yang terdiri dari kategori tinggi, sedang, dan rendah. Berdasarkan hasil kategori minat belajar, bahwa tingkat minat belajar matematika siswa kelas $\mathrm{V}$ berada pada kategori tinggi frekuensinya sebesar 8 siswa dengan persentase $35 \%$, pada kategori sedang frekuensinya sebesar 11 siswa dengan persentase $55 \%$, dan pada kategori rendah frekuensinya sebesar 2 siswa dengan persentase $10 \%$. Hal ini menunjukkan minat belajar matematika siswa kelas V SD Negeri 04 Sila berada pada kategori sedang.

\section{Deskripsi Hasil Belajar}

Data Hasil Belajar

Data hasil belajar matematika diperoleh dengan menggunakan teknik dokumentasi. Dokumentasi yang digunakan yaitu nilai hasil ujian tengah semester (UTS) semester genap. Berdasarkan data hasil belajar yang diperoleh siswa mempunyai nilai terendah 48 dan nilai tertinggi 91 .
Kategori Hasil Belajar

Tingkat hasil belajar matematika siswa kelas V dapat diketahui dengan cara penentuan kategorisasi yang terdiri dari kategori tinggi, sedang, dan rendah. Berdasarkan kategori hasil belajar bahwa tingkat minat belajar matematika siswa kelas $\mathrm{V}$ berada pada kategori tinggi frekuensinya sebesar 4 siswa dengan persentase $20 \%$, pada kategori sedang frekuensinya sebesar 9 siswa dengan persentase $45 \%$, dan pada kategori rendah frekuensinya sebesar 7 siswa dengan persentase $35 \%$. Hal ini menunjukkan minat belajar matematika siswa kelas V SD Negeri 04 Sila berada pada kategori sedang.

Pengujian hipotesis digunakan untuk mengetahui dugaan sementara atau jawaban sementara yang dirumuskan dalam hipotesis penelitian. Pengujian hipotesis bertujuan untuk menetapkan ada tidaknya hubungan antara minat belajar dengan hasil belajar matematika kelas $\mathrm{V}$ SD Negeri 04 Sila. Untuk menguji hipotesis penelitian ini, digunakan teknik korelasi product moment. Uji ini digunakan untuk menguji hubungan antara minat belajar dengan hasil belajar matematika pada siswa kelas V SD Negeri 04 Sila. Uji korelasi product moment yang dilakukan peneliti berdasarkan kriteria pengujian yaitu jika $r_{\text {hitung }} \geq r_{\text {tabel }}$, maka hipotesis alternatif $\left(H_{a}\right)$ diterima yaitu terdapat hubungan antara minat belajar $(\mathrm{X})$ dengan hasil belajar matematika siswa $(\mathrm{Y})$. Namun jika $r_{\text {hitung }}<r_{\text {tabel }}$ maka hipotesis nihil $\left(H_{0}\right)$ diterima yaitu tidak terdapat hubungan antara minat belajar matematika $(\mathrm{X})$ dengan hasil belajar matematika siswa (Y), dengan taraf signifikansi $(\alpha)=5 \% n=20$.

Berdasarkan hasil perhitungan yang telah dilakukan secara statistik, diperoleh hasil penghitungan $X=1067, Y=1280, X 2=57531, Y 2=$ 85192 dan $\mathrm{XY}=68548$. Hasil perhitungan ini kemudian dianalisis secara statistik melalui rumus hipotesis korelasi product moment agar bisa diketahui berapa besar koefesien korelasi antara variabel $\mathrm{X}$ dengan variabel $\mathrm{Y}$.

Berdasarkan hasil perhitungan yang telah dilakukan secara statistik, diperoleh hasil perhitungan $X=1067, \quad Y=1280, \quad X^{2}=57531$, $Y^{2}=85192$ dan $X Y=68548$. Hasil perhitungan ini kemudian dianalisis secara statistik melalui rumus 
hipotesis korelasi product moment agar bisa diketahui berapa besar koefesien korelasi antara variabel $\mathrm{X}$ dengan variabel $\mathrm{Y}$. Melalui perhitungan tersebut diperoleh hasil $r_{x y}$ atau $r_{\text {hitung }}=0,584$ dengan taraf signifikansi $5 \%$ dan $r_{\text {tabel }}=0,444$. Dari hasil perhitungan tersebut menunjukkan bahwa $r_{\text {hitung }} \geq r_{\text {tabel }}$, dengan interpretasi nilai $\mathrm{r}$ agak rendah, maka dapat disimpulkan bahwa hipotesis alternatif $\left(H_{a}\right)$ diterima dan $H_{o}$ ditolak, bahwa terdapat hubungan yang agak rendah antara minat belajar matematika dengan hasil belajar matematika siswa kelas V SD Negeri 04 Sila.

Berdasarkan hasil perhitungan diperoleh nilai uji $\mathrm{t}$ untuk variabel minat belajar matematika siswa dengan nilai $t_{\text {hitung }}$ sebesar 3.019 . Selanjutnya nilai $t_{\text {hitung }}$ dibandingkan dengan nilai $t_{\text {tabel }}(n-2)$ dengan taraf signifikansi $(\alpha)$ 0,05 dipeoleh $t_{\text {tabel }}$ sebesar 1,734. Karena $t_{\text {hitung }}$ lebih besar dari $t_{\text {tabel }}$, maka terdapat hubungan yang agak rendah antara minat belajar dengan hasil matematika siswa. Sedangkan koefisien determinasinya sebesar $43,1 \%$ artinya bahwa minat belajar memberikan pengaruh sebesar 43,1\% terhadap hasil belajar matematika siswa kelas V SD Negeri 04 Sila.

Dari hasil perhitungan korelasi product moment variabel $\mathrm{X}$ dan $\mathrm{Y}\left(\mathrm{r}_{\mathrm{XY}}\right)$, didapatkan $\mathrm{r}_{\text {hitung }}$ 0,584, yang lebih besar dari $r_{\text {tabel }}$ sebesar 0,444, hipotesis diterima dengan interpretasi (tingkat hubungan) agak rendah. Berdasarkan penjelasan diatas, dapat disimpulkan bahwa terdapat hubungan antara minat belajar dengan hasil belajar matematika siswa kelas V SD Negeri 04 Sila.

Berdasarkan tujuan penelitian yang telah dikemukakan pada Bab 1 yaitu ingin mengetahui ada atau tidaknya hubungan antara minat belajar dengan hasil belajar matematika pada siswa kelas V SD Negeri 04 Sila. Serta ingin membandingkannya dengan kajian teori yang menyatakan bahwa minat belajar siswa merupakan salah satu faktor yang dapat mempengaruhi hasil belajar siswa. Untuk itu peneliti akan membahas lebih rinci mengenai hasil penelitian yang dihasilkan oleh peneliti yang akan dibandingkan dengan kajian teori.
Berdasarkan uji hipotesis, minat belajar matematika terhadap hasil belajar matematika menunjukkan hubungan dengan nilai $r_{\text {hitung }}$ sebesar 0,584, sedangkan nilai $r_{\text {tabel }}$ sebesar 0,444 . Berdasarkan data tersebut, nilai $r_{\text {hitung }} \geq$ $r_{\text {tabel }}$, maka hipotesis diterima, artinya terdapat hubungan antara minat belajar dengan hasil belajar matematika siswa kelas V SD Negeri 04 Sila. Minat belajar matemaika memberikan pengaruh sebesar $34,1 \%$ terhadap hasil belajar matematika.

Berdasarkan uraian di atas, maka dapat ditegaskan bahwa terdapat Hubungan antara minat belajar matematika dengan hasil belajar matematika siswa. Hal ini juga telah diungkapkan oleh Slameto dalam bukunya yang berjudul (belajar dan factor-faktor yang mempengaruhi pada halaman 59) minat adalah suatu rasa lebih suka dan rasa ketertarikan pada suatu hal atau aktifitas, tanpa ada yang menyuruh. Oleh karenanya ketika siswa memiliki minat terhadap suatu mata pelajaran tertentu, maka hal tersebut akan memberikan sumbangan positif terhadap hasil belajar siswa kearah yang lebih baik.

Hasil ini didukung juga oleh pernyataan Syaiful Bahri Djamarah (2002: 132), bahwa seseorang yang memiliki minat terhadap suatu aktivitas, akan memperhatikan aktivitas itu secara konsisten disertai rasa senang. Konsistensi dalam melaksanakan kegiatan belajar yang dilakukan siswa dan disertai dengan perhatian yang tinggi akan membantu siswa menambah pengetahuan dan pemahaman pada materi yang dipelajarinya. Syaiful Bahri Djamarah (2002:132) menambahkan minat pada dasarnya adalah penerimaan akan suatu hubungan antar diri sendiri dengan sesuatu di luar dirinya. Semakin kuat dan dekat hubungan tersebut, semakin besar minat yang ada. Hal ini menjadi dasar baik bagi guru, orangtua, serta lingkungan untuk dapat mendukung tumbuhnya minat pada diri siswa untuk belajar. Dengan demikian hipotesis dapat diterima dan terbukti.

\section{SIMPULAN}

Berdasarkan hasil penelitian dan pembahasan maka dapat diperoleh beberapa kesimpulan sebagai berikut: 1) Minat belajar siswa kelas V SD 
Negeri 04 Sila berada pada kategori sedang dengan persentase sebesar 55\% dari 20 siswa; 2) Hasil belajar matematika siswa kelas v SD Negeri 04 Sila berada pada kategori sedang dengan persentase sebesar 45\% dari 20 siswa; 3) Hasil perhitungan uji hipotesis minat belajar terhadap hasil belajar matematika menunjukan nilai $r_{\text {hitung }}=0,584>r_{\text {tabel }}=0,361$ (taraf signifikan 5\%) dan nilai $t_{\text {hitung }}=3,019>t_{\text {tabel }}=1,734 \quad(n-2$ dengan taraf signifikansi $(\alpha) 0,05)$ maka $H_{a}$ diterima dan $H_{0}$ ditolak, yang artinya bahwa terdapat hubungan antara minat belajar dengan hasil belajar matematika pada siswa

\section{DAFTAR PUSTAKA}

Adiansha, A. A., Sumantri, M. S., Makmuri, M., \& Asriyadin, A. (2017). The Effect of Brain Based Learning Model and Creative Thinking about the Ability of Mathematics Concept of Elementary Students. American Journal of Educational Research, 5(12), 1195. 1199.

Arikunto, Suharsimi. (2006). Prosedur Penelitian Suatu Pendekatan Praktik. Jakarta: Rineka Cipta.

Arikunto, Suharsimi. (2006). Dasar-Dasar Evaluasi. Jakarta: Bumi Aksara,

Azwar, Saifuddin. 2011. Penyusunan Skala Psikologi. Yogyakarta: Pustaka Belajar.

Dalyono, M. (2007). Psikologi Pendidikan. Jakarta: Rineka Cipta.

Djamarah, Bahri. (200)2. Psikologi Belajar. Jakarta: Rineka Cipta

Hamdani. (2011). Strategi Belajar Mengajar. Bandung: Pustaka Setia.

Hurlock, Elizabeth B. (2005). Perkembangan Anak Jilid 2. (Alih Bahasa: dr. Med. Meitasari Tjandrasa). Jakarta: Erlangga.

Ibrahim, \& Suparni. (2008). Strategi Pembelajaran Matematika. Yogyakarta: Bidang Akademik UIN.

Martono, Nanang. (2011). Metode Penelitian Kuantitatif. Jakarta: Raja Grafindo Persada.

Pidarta, Made. (2007). Landasan Pendidikan. Jakarta: Renika Cipta.
Riduwan. (2012). Belajar Mudah Penelitian untuk Guru-Karyawan dan Peneliti Pemula. Bandung: Alfabeta.

Riduwan dan Susanto. (2009). Pengantar Statistika: Untuk Penelitian Pendidikan, Sosial, Ekonomi Komunikasi dan bisnis. Bandung: Alfabeta.

Sarjono, Haryadi. (2011). SPSS vs LISREL Sebuah Pengantar Aplikasi untuk Riset. Jakarta: Salemba Empar.

Slameto. (2003). Belajar dan Faktor-Faktor yang Mempengaruhinya. Jakarta: Rineka Cipta.

Slameto. (2010). Belajar dan Faktor-Faktor Yang Mempengaruhinya. Jakarta: Rineka Cipta.

Sudjana. (2005). Metode Statistik. Bandung: Tarsito.

Sugiyono. (2007). Metode Penelitian Pendidikan: Pendekataan Kuantitatif, Kualitatif, dan REDD. Bandung: Alfabeta.

Sugiyono. (2009). Metode Penelitian Kuantitatif Kualitatif dan REDD. Bandung: Alfabeta.

Sugiyono. (2003). Undang-undang Republik Indonesia Nomor 20 Tahun 2003 tentang Sistem Pendidikan Nasional. Jakarta: Departemen Pendidikan Nasional Republik Indoneisa.

Sugiyono. (2010). Metode Penelitian Pendidikan. Bandung: Alfabeta

Sukmadinata, \& Nana Syaodih (2013). Metode Penelitian Pendidikan. Bandung: Remaja Rosdakarya.

Susanto, Ahmad.

TeoribelajarËpembelajaran di sekolahdasar. Jakarta: Kencana.

Susanto, Ahmad. (2013). Psikologi Pendidikan Dengan Pendekatan Baru. Bandung: Remaja Rosdakarya.

Syah, Muhibbin. (2013). Psikologi Pendidikan dengan Pendekatan Baru. Bandung: Remaja Rosdakarya. 